\title{
KARIM VE KIZIM OYUNUNDA DEĞERLER ÇATIŞMASI
}

\section{Nurullah Cetín}

Recep Bilginer'in iki bölümlük Karım ve Kızım (1985) adlı oyunu, Türk toplum hayatında sosyo-ekonomik gelişmelere bağlı olarak ortaya çıan özü kavranmamış bir modernleşme sürecinin doğurduğu değerler çatışması ve farkh hayat anlayışları üzerine kurulmuş.

Dünyayı ve hayatı algılay'p değerlendirme açısından farklılaşan bu değerleri, Kemal Rifat ailesi ve bu ailenin çevresinde yer alan bazı kişiler temsil etmektedirler.

Kemal Rifat'ın karısı İncila ve şirketinde çalışan M. Sami gibi kişiler, maddenin yani somut dünya varlığının birincil konumda tutulduğu ve buna bağlı olarak yüce insanî değerlerin geri plâna itildiği, yozlaşmış bir dünya görüşünü temsil eden tipler olarak yer alırken; Ş. Yılmaz maddeci olmayan, insanlı, dostluk ve sevgi gibi değerleri ön plâna alan bir tiptir.

Bu yazıda hayata bakıştaki bu karşıtlıkları kişilerin temsileiliğinde, onların düşüncelerini ve yapıp-etmelerini sergileyerek göstermeye 'çalışacağız.

Kemal Rifat, daha önceleri küçük bir memur olup, sade ama mutlu bir hayat yaşamaktadır. Ancak sonraları iş dünyasına girerek holding sahibi olmuştur. Oldukça zenginleşir ve büyük bir evde müreffeh bir hayat yaşamaya başlar. Ekonomik anlamdaki varlığa dayalı bu yeni yaşantı, Kemal Rifat, karısı İncilâ ve kızı Aysel'in hayata bakış açılarını birdenbire değiş̧tirir.

İncila, sonradan edindiği ayricalıklı ekonomik ve sosyal konumunu çevresiyle olan sosyal ilişkilerinde kötü, olumsuz duygu ve düşüncelerinin tatmini için bjr arą̧ olarak kullamr. Örneğin dostlarına bir parti verir. Bu şölen; arkadaşlarına onlardan daha üstün olduklarını göstermek, kıskandırmak, gazete ve dergilerin sayfalarına geçmek amaciyla düzenlemiştir.

İncila, kocasını sürekli daha çok zengin olmaya teşvik eder. Amacı, çevresini daha çok kıskandırmaktır. Moda evlerine, mobilya mağaza- 
larına sık sık gider gelir. Çok para harcar, görgüsüz, savurgan ve zengin bir hayat yaşar.

Ayrica İncila'nın çevresinde maddî değerleri ve menfaat ilişkilerini ön plâna alan ve günübirlik hazza dayalı yaşama üslûbunu benimsemiş kimseler bulunmaktadur. Bunlar arasında Selda gibi erkek delisi dul kadınlarm yanında Mehmet Sami önemli bir role sahiptir.

M. Sami, K. Rifat'ın şirketinde çalışan ve patronunun şirketlerine gözünü dikmiş bir çıkarcıdır. K. Rifat'ın kızı Aysel'le evlenip holdingine sahip olmak istemektedir. Bunun için İncila'yla daha önce kurduğu yasak ilişkiyi koz olarak kullanır. Eğer Aysel'le evlenmesine yardımeı olmazsa skandala yol açacak fotoğrafları ifşa edeceğini söyler.

K. Rifat, böyle bir evlilik fikrini onaylar. Çünkü Sami Bey, madde adamıdır. Onun için şirketlerine öyle biri gereklidir. (s. 43)*

M. Sami'nin bütün düşüncesi şu ifadelerinde yerini bulmaktadır:

"Benim de bir zayıf yanım var. Para. Ben büyük şirketlerim, büyük kuruluşlarım olsun isterim. Emrimde insanlar çalışsın. Onlara hükmedeyim. Aysel'le evlenirsem Kemal Rifat Bey, beni şirketlerinin başına geçirecek. Göz göre göre nasıl kaçırırım bu fursatı?"' (s. 50)

Maddeci değer yargıları doğrultusunda yaşantısını sürdüren bir başka kişi de K. Rifat'in kızı Aysel'dir. Aysel, şımarık, üniversiteyi yarıda bırakmış, sürekli otomobil değiştiren, gezip tozan ve su gibj para harcayan birisidir. Derinlikli hiç bir düşüncesi yoktur. Dış görünüşü itibariyle bir oyuncak bebeği andırır. Sorumluluk ve amą̧ taşımaz. Sanki bir insan kuklasııdır. 0 istediği her şeye ulaşmış ve kendisine verilen hayatı yaşamıştır.

Önceleri K. Rifat, kendisinin zamanında sskıntı çektiğini; dolayısıyla ailesinin istediği gibi harcayarak gönüllerince yaşamaları gerektiği düşüncesiyle onları serbest bırakır.

Oyunun başhıca kişilerinden bini de Şevki Yılmaz'dır. O, Kemal Rifat, Incila, Mehmet Sami ve Aysel gibi kişilerin temsil ettiği yüzeysel ve amaçsız maddeci dünya görüşüne ve olumsuz değerlere karşı manevî ve insanî değerler bütününü temsil eden bir tiptir. Ş. Yılmaz'm sahneye çıkışıyla birlikte bu karşıt değerlerin sürekli ̧̧arpışmasına tanık olmaktayiz.

* Bundan sonra vereceğimiz sayfa numaraları, şu kaynaktan alınmıştır: Recep Bilginer, Karım ve.Kızım, Devlet Tiyatrolan Genel Müdürlüğ̈̈, 26.12.1985. 
Ş. Yılmaz, varlıklı olmayan ve sade bir hayat yaşayan bir edebiyat öğretmenidir. Kemal Rifat ailesine gelir gider. Bu arada Aysel'le evlilikleri söz konusu edilir.

Ş. Yılmaz-Aysel diyaloglarında maddî ve manevî değerler çatışmasını somut olarak görmekteyiz. Ş. Yılmaz, Aysel'e dış özelliklerine, güzelliğine ve varlığına değil; iç dünyasına önem verdiğini vurgular. Onun için Aysel'in neler düşünüp neler duyduğu önemlidir. Tartışmalarında ona alışkanlıklarını bırakarak değişmesi gerektiğini telkin eder.

Diğer yandan M. Sami, Aysel'in Ş. Yılmaz'la beraberliğinden rahatsız olur ve Aysel'e sınıf farkını vurgulayarak şunları söyler:

"Bizim dengimiz değil. Sen ve ben toplumun üst tabakasındanız! O bizim seviyemize çıamą, biz de onunkine inemeyiz. Onu aramıza sokmamaliyız" (s. 17)

Ancak zaman içerisinde Aysel, Ş. Yılmaz'ı ve fikirlerini beğenmeye başlar. Bu durum, aynı zamanda Aysel'in kişiliğinde olumsuz ve kötü olan değer yargılarının olumlanan değerlere doğru evrilmesi gelişimini de sembolize etmektedir. Ş. Yılmaz, düşünceleri ve kişiliğiyle kendisini fakir bir öğretmen; ama bilgili biri olarak gösterir. Aysel, onunla birliktelikten mutluluk duyar, babasının şirketinde işe girerek çalışmaya başlar ve böylece belli bir amą̧ ve sorumluluk üstlenir. Hatta, Ş. Ýlmaz'in uzak semtteki küçük evinde annesiyle birlikte sade bir hayat yaşamayı bile kabul eder. Eski anlayış ve davranışlarından sıyrılarak yeni bir kișilik kazanır.

Ancak Kemal Rifat, kızının Ş. Yılmaz'la evlenmesi düşüncesine karşı çıkar. Çünkü Ş. Yılmaz, her ne kadar kişilik ve manevî özellikler bakımindan Aysel'i mutlu etmeye yeter biri ise de, şirketleri idare edecek özelliklere sahip değildir. Ticaret konularıyla ilgili değildir. Ekonomiden anlamaz. Halbuki K. Rifat'ın kızı için maneviyat adamı, şirketleri için de madde adamı lâzımdır. Bundan dolay: kızı iȩin şirketlerini, şirketleri için de kızının mutluluğunu tehlikeye atmak istemez.

K. Rifat, maddenin yeter çözüm olduğu düşüncesini bir savunmasinda şöyle dile getirir:

"Ben çok zenginim, bozuklukları düzeltecek kadar, para her şeyin üstünde bir kalkandır kızım. Çirkini güzel yapar, kötüyü iyi. Biz güçlüyüz kızım. Toplumda ayrıcalığımız var. Bunu kullanırız." (s. 47-48) 
Bu ortamda madde-mânâ çekişmesi Aysel'e sahiplenme kavgasinda yoğunlaşır. Ş. Yılmaz, iyi niyetli ve olumlu düşünceleriyle onu kazanmaya çalışırken, Mehmet Sami de art niyetli düşünceleriyle onu eski hâline döndürmeye çalışır. Ona çalışmayı bırakmasını, çok yıprandığını, çiçek gibi solduğunu söyleyerek "sen ancak bizim aramızda kendine gelirsin" (s. 49) yollu telkinleriyle temsil ettiği çevrenin kavgasını verir.

Ş. Yılmaz ise bu çatışmada olumlu düşüncelerinin vermeye başladığı meyvenin boşa gitmesinden endişe eder:

"Ona çok emek verdim, boşa gitmesini istemem. Aysel'i bir süs çiçeği olmaktan kurtarmıştım. Kuklalıktan çıkıp, yaşayan bir insan yapmıştım. Topluma yaxarlı bir inšn!?’ (s. 69)

Oyunda vurgulanan önemli bir konu da tamamen maddeye dayalı değer yargılarıyla donanımlı olan Íncila çevresinin kendi içinde düzenli ve sağlıklı ilişkilerin bulunmaması; bu ilişkilerin çıkar çatışmaları, kin, intikam, ibtiras, kıskançlık ve gösteriş gibi olumsuz duygularla sarmalanmış olması. Bu çarpıklığın temelinde "para"nın öncelikli konumda tutulması olgusu önemli bir yer tutmaktadır. Nitekim evin hizmetçisi Adıgüzel, gözlemlerine dayalı olarak bu durumu şöyle vurgular:

"Para insanı dellendiriyor mu ne?" (s. 72)

Ayrica farklı değerler çatışmasının bir başka boyutunun da kentköy karşıtlığında sergilendiğini görüyoruz.

"Kent", para merkezli çirkinlik ve yozlukları, sapmaları ve mutsuzlukları sembolize ederken; "köy" de maddenin geri plândakaldığı, sadelik, dürüstlük, doğallı ve huzur gibi olumlanan değerleri temsil eder.

Adıgüzel ve Safiye, Kemal Rifat'in evinde hizmetçi olarak çalışmaktadırlar. Bunlar evlenip köylerine dönmeyi plânlarlar. Adıgüzel, Safiye'yle konuşurken kent-köy karşıtlığını vermesi açısından ilginȩ bulduğumuz şu cümleyi söyler:

"Bırak burası burda kalsın. Köyümüz bize yeter" (s. 73)

"Adıgüzel-Biz yoku var edelim Safiye. Birbirimize arka çıarak. $\mathrm{Bu}$ evdekiler gibi olmayalom.

Safiye-He, olmayalım. (Uşaka iyice sokulur). Her şeyleri var. Gel gör ki dirlik düzenlikleri yok." (s. 74)

Zaman içerisinde önemli bir gelişme ortaya çıkmaktadı̣. K. Rifat, içinde bulunduğu çevrenin çürümesini ve tüm olumsuzluklarını görür. 
Yavaş yavaş her şeyiu farkına varır. Bunaldığı yanlış dünyasını evlenmek isteyen hizmetçilerine ögüt bağlamında şöyle itiraf eder:

"Birbirinize hiç yalan söylemeyin. Senin ona, onun sana karșı hiç gizliniz, saklınız olmasın. Ne olursa, önce birbirinize söyleyin. Siz evlilik ve yuva nedir biliyor musunuz? Bir tapınak gibi kutsaldır. Onu kirletmek nasıl günahsa yuyayı kirletmek de günahtır. Hep temiz tutun yuvanız, temiz! Kirletmeyin. Bu da karşılıkh sevgi ve saygıyla olur." (s. 76)

Kemal Rifat, hayatının anlamını yeniden sorgulamaya başlar. Aile mutluluğu artık onun için hayatunda öncelikli bir konuma gelmiştir. Ailesi için yaşadığı, para, mal ve mülkün ailesi yanında hi̧̧ bir değeri olmadığı düşüncesini ifade eder. Karısı ve kızını yanlışlarından uyarmaya çalışır. Artık bundan böyle toplantılara da davetlere de paydos çağrısında bulunur. "Kapılarımızı kapayalım aramıza yabaneı girmesin" der. Çünkü kendi kendilerine kalınca birbirlerine daha çok yakınlaşacaklardır. Artık o, eski orta hâlli, sade ama mutlu günlerini özlemektedir.

K. Rifat'ın olumlu yöndeki değişimini şu ifadeleri somut olarak ortaya koymaktadir:

"Artık değiştim. Ne bu büyük ev, ne hizmetçi, ne uşak. Hiçbirini istemiyorum. Bir tek sen, ama ilk günlerin Incila's' bana yeter" (s. 82)

K. Rifat, aile mutluluğunu ortadan kaldıran asıl nedeninin serveti olduğu düşüncesiyle bütün varını yoğunu dağıtır. Bu olay karşısında K. Rifat ve karısı İncila'nın farklı tepkileri, başından beri irdelemeye çalıştığımız değerler çatışmasını, karşıt dünya görüşlerini net bir şekilde ortaya koymaktadur.

"İnei'a-Giyinip kuşanmadan bol para harcamadan başkalarına gösteriş yapmadan ben nasıl yaşarım?

K. Rifat-Ya ben, onurumu kurtarmadan nasl yaşardım?" (s. 92)

Oyunun adın oluşturan "Karım ve Kızım" ifadeleri de üzerinde durduğumuz konuyu çağrışımlarla çarpıei biçimde yoğunlaştırmaktadır.

Oyun, "aile" toplum birimi merkez alnarak ve "baba-karisı ve kızı" ve başka kișilerle eanlı kılınarak toplumumuzda önemli bir yeri olan bazı sosyo-ekonomik sorunlan sergilemiştir.

Üzerinde durulan en önemli husus da, insanî ve manevî değerlerle yönlendirilmemiş ve anlamlandırılmamış maddî varlığın ị̧ dünya 
zenginliğinden yoksun insanlar elinde onları nasıl yıkıma uğrattığı vurgusudur.

Bu durumu K. Rifat, çarpıcı ifadelerle şöyle ortaya koymaktadır:

"Benim aile düzenimi korumayan serveti ne yapayım ben? 0 servet, karımı ve kızımı benden aldı. Onlara da âlî onurunu, insanlıkların unutturdu." (s. 93)

Sonuç olarak denilebilir ki, ekonomik, sosyal ve teknolojik alanlarda gelişim ve değişim gösteren toplumlar, aynı zamanda anlayış, düşünce ve değer çatı̧̧alarına sahne olmaktadırlar. 